\title{
トマト果梗における物理的処理後の組織形態の変化
}

\author{
鈴木克己 ${ }^{1 a} *$ ・木村一郎 ${ }^{2} \cdot$ 河崎 $\quad$ 靖 ${ }^{3}$ •安場健一郎 ${ }^{1} ・$ 東出忠桐 ${ }^{1}$ \\ 1 農研機構野菜茶業研究所 305-8666 茨城県つくば市観音台 \\ 2 山口農林事務所 753-0064 山口県山口市神田町 \\ 3 農研機構野菜茶業研究所 $470-2351$ 愛知県知多郡武豊町
}

\section{Morphological Studies on Change of Peduncle after Physical Treatment in Tomato}

\author{
Katsumi Suzuki $^{1 a *}$, Ichiro Kimura ${ }^{2}$, Yasushi Kawasaki ${ }^{3}$, Ken-ichiro Yasuba ${ }^{1}$ and Tadahisa Higashide ${ }^{1}$ \\ ${ }^{I}$ National Institute of Vegetable and Tea Science, Kannondai, Tsukuba, Ibaraki 305-8666 \\ ${ }^{2}$ Yamaguchi Agricultural Office, Kanda, Yamaguchi, Yamaguchi 753-0064 \\ ${ }^{3}$ National Institute of Vegetable and Tea Science, Taketoyo, Chita, Aichi 470-2351
}

\begin{abstract}
It was reported that the incidence of fruit cracking decreased with twisting of the peduncle in tomato. However, the detailed process in the peduncle was unclear after physiological treatment. In this study, we observed morphological changes in the peduncle during tomato fruit development after physiological treatment. One day after treatment, the secondary xylem detached from the cambium, the inner space expanded in the pith and cortex, and cell arrangement was disordered in the cambium. Three days after treatment, a thin cell wall was newly observed around the phloem, and callus tissue with meristic cells was formed around the inner phloem and cambium. Hypertrophic cells appeared in a detached region near the cambium. Five to nine days after treatment, wound vessels, wound phloem, and new cambium differentiated and spread in the callus, and connected with the vascular system of the normal region in the peduncle. From these observations, it was suggested that the pathway of vascular bundles was destroyed with physiological treatment, but a new connection of vascular bundles with callus formation was constructed again, and the supply system conveying nutrients for fruit development was reorganized.
\end{abstract}

Key Words : anatomy, callus, fruit cracking, hydroponics, vascular bundle

キーワード : 維管束, 解剖学, カルス, 裂果, 養液栽培

\section{緒言}

生育中に果実表面が裂ける裂果は，トマト栽培に打ける 深刻な生理障害である。裂果は高温，高湿度，日較差大， 強日射条件などの環境下に拈いて，着果負担低，ソース／ シンク比大, 低頻度・多量の灌溉, 塩類バランスの崩れ, 低 ECなどの要因により発生する（Dorais ら，2004）。我が 国の夏秋トマトに扣いても深刻な問題となっており, 茥葉 や果実に日射が当たりやすい条件で発生しやすく（鈴木・ 柳瀬, 2005), 特に, 幼果期〜緑熟期頃までの積算日射量が 多く肥大が旺盛な果実で生じやすいことが示されている (鈴木ら，2007). また，日ごとの飽差の差と裂果発生には 正の相関が見られることが報告されている（渡邊ら, 2006).

2012 年 1 月 6 日 受付. 2012 年 3 月 22 日 受理.

本研究は農林水産省委託プロジェクト研究「気候変動に対応し

た循環型食料生産等の確立のための技術開発」に打いて行わ机

た. また本報告の概要は園芸学会平成 22 年度秋季大会, 平成 23

年度秋季大会で発表した.

* Corresponding author. E-mail: skatsumi@affrc.go.jp

a 現在 : 470-2351 愛知県多群式豊町
裂果発生に伴ら果実表面の亀裂の入り方は様々で，表皮 のクチクラ層および表皮細胞の間が裂けて広がり，ひどい ものでは果実の上部半分に何本もの裂け目が入るものもあ る. 正常な果実では果実の肥大に伴い表層の細胞の肥大と クチクラ伸張のバランスがとれて肥大寸るが，裂果では果 実への急激な水分流入によりバランスが崩れ，表面に亀裂 を生じるとされている（Doraisら，2004）.

裂果発生を抑制する対策として，発生要因となる環境を 制御するため, 株全体の遮光, 果実遮光, 近赤外線除去フィ ルムの利用などが示されている（雨ヶ谷ら，1984; 野村ら， 2006; 鈴木ら，2009; Wada ら，2006)。これらの対策は特別 な資材が必要であり，遮光資材の展張に伴ら光量低下によ る収量の減少も懸念される。資材を利用しない裂果対策と して，山下ら（1994）は，果実への水分流入を阻止するた め，果梗部を収穫直前にペンチで強く捻枝することが有効 であることを示した．しかし，果梗をペンチで捻枝するこ とが，水の流入経路である維管束にどのようなダメージを 与光, 果実への水分流入を阻止するのかについて詳細なこ とは分かっていない，果梗を捻枝する場合には，果梗の内 
部形態を考慮し, ぞの部位にダメージを与え, 水分流入を 減少させるかイメージすることが必要と思われる. そこで, 本研究では, 山下ら（1994）が提唱したペンチによる捻枝 処理が裂果発生に及ぼす影響を再検討し, 果梗が物理的処 理を受けた場合の内部構造の変化, および果実の肥大に及 ぼす影響について調査した。

\section{材料および方法}

\section{1. 物理的処理が裂果発生に及ぼす影響}

野菜茶業研究所武豊野菜研究拠点内で, トマト (Solanum lycopersicum L.）‘ビットリオ’（朝日工業）を2009年 6 月 1 日に播種し，閉鎖型苗生産システムで一次育苗を用い，6 月 28 日にロックウールキューブに鉢上げし，7 月 10 日に 敷地内にある超低コストハウス（高市，2007）内に設置し た長さ $90 \mathrm{~cm}$ のロックウールスラブに 4 本ずつ定植した. 1 本仕立てとし, $\mathrm{EC} 0.8 \sim 1.2 \mathrm{ds} \cdot \mathrm{m}^{-1}$ （大塚 $\mathrm{SA}$ 処方）の養 液で掛け流し栽培した。各果房の第 $1 \sim 4$ 花以外は除去し た. 果梗への処理として, 第 1 果房を 8 月 17 日, 第 2 果房 を 8 月 25 日，第 3 果房を 9 月 4 日に，切り込久処理（カッ ターで果梗の半分にくさび状に切り込みを入れた), 中心部 圧迫処理（凹凸状の電工ペンチで果梗部位の中心部分を押 し潰した), 捻枝処理 (ペンチで組織が潰れる程度強く挟ん だ）した．各処理を，離れて配置した 4 スラブに植えた 16 株ずつに対して行った. 催色期〜桃熟期の果実を収穫し, 各処理に打ける果実重と裂果の発生について調査を行っ た. 各果房の収穫時期は第 1 果房では果梗処理 $2 \sim 5$ 日後, 第 2 果房では果梗処理 $8 \sim 10$ 日後, 第 3 果房では果梗処理 7 ～ 10 日後であった. 裂果は $1 \mathrm{~cm}$ 以上の亀裂を有したも のをすべて裂果とした，各処理区について，各果房におけ る総果数と裂果数から裂果率を算出し, 果重を調査した.

\section{2. 物理的処理後の組織内部形態の変化}

トマト品種 ‘桃太郎ヨーク’を播種し, 一次育苗と二次 育苗を行い, 2010 年 8 月 12 日に NFT システムに定植した. 使用した温室や温室内のベッド配置, 栽培システムは前報 と同様である（鈴木ら，2011; Suzuki ら，2011）。9月 22 日 に第 2 果房の果柄を捻枝処理した。第 2 果房の果実は 9 月 29 日〜 10 月 29 日に収穫された。 処理前，処理 1，3，7 抒 よび 9 日後にそれぞれ 3 個体から果柄の捻枝処理部分を切 り離し， $3 \%$ グルタルアルデヒドと $1 \%$ パラホルムアルデヒ ドの混合溶液で約 16 時間固定した. その後, エタノールシ リーズで脱水し，テクノビット 7100 に包埋した. $2 \mu \mathrm{m}$ の 準超薄切片を作成し，トルイジンブル一溶液で染色し，顕 微鏡（BX50，オリンパス）で観察した.

\section{3. 物理的処理が果実肥大に及ぼす影響}

2010 年 12 月 9 日にトマト品種 ‘桃太郎ヨーク’を上記 と同じ NFT システムに定植した. 配置した 4 本の栽培ベッ ドに，各列 20 本ずつ定植し，東西に振り分けて誘引した. 第 1 果房について果実肥大後，果実数を 4 果に揃光，果実 肥大期の 2011 年 3 月 9 日に果梗を捻枝処理した. 捻枝処理
は内側の 2 本の栽培ベッドの東西に振り分けた 4 列につい て 3 株ずつの計 12 株で行った。 また，それぞれの列の捻枝 処理を行っていない 3 株ずつの計 12 株を対照とした. 第 1 果房の果実は 3 月 16 日〜 4 月 1 日に収穫された. 果房の果 実の直径を，処理 7,5 および 3 日前，処理当日，処理後 2, 4 扎よび 7 日にデジタルノギスで調査した。各果房の果 実の直径の平均を算出し, 処理日の果実直径值を 1 として, 処理前と処理後の果実の相対值を算出した. 処理前の果実 生長を揃えるため処理 5 日前の值が $0.922 〜 0.977$ の果実を それぞれ 18 個ずつ選びグラフを作成した. 処理日の果実の 直径の平均は $5.31 \mathrm{~cm}$ であった.

\section{結果}

\section{1. 物理的処理が裂果発生に及ぼす影響}

7 月に定植し, 8 抢よび9月に収穫した果実のほとんどの ものは， $1 \mathrm{~cm}$ 以上の亀裂を有する裂果であった。 それぞれ の果房の収穫前にトマトの果梗をカッターにより約半分に くさび状に切れ込みを入れた切り込及処理, 凹凸状のペン チで果梗の中心部分を潰した中心部圧迫処理，ペンチで果 梗を全体的に強く潰した捻枝処理を行った結果，裂果発生 率は，捻枝処理で無処理と比べて有意に減少した（第 1 図 A).一方，収穫した果実の重量では，処理間および無処理 との間で有意差は認められなかった（第 1 図 B).
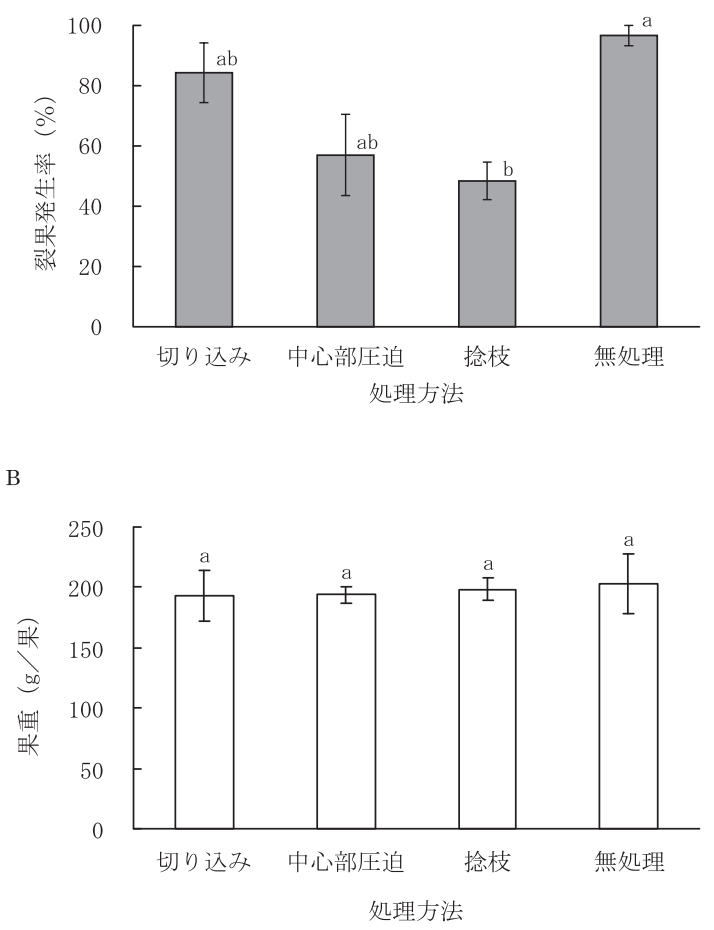

第 1 図 果梗への処理方法の違いによる裂果発生率 (A) と果重 (B)

第 $1 \sim 3$ 果房の平均

アルファベットが異なる場合，Tukey の多重検定（5\% 水準）による有意差あり 


\section{2. 物理的処理後の組織内部形態の変化}

第 2 図 A は発達中の果梗の横断面である。トマト果梗は 外側から，表皮(第 2 図 $\mathrm{A} ， \mathrm{e}$ )，皮層（第 2 図 $\mathrm{A} ， \mathrm{ch}$ から op の間), 形成層（第 2 図 $\mathrm{A}, \mathrm{c}$ ), 二次木部 (第 2 図 $\mathrm{A}, \mathrm{sx}$ ), 髄（第 2 図 $\mathrm{A}, \mathrm{px}$ 上り内）に分けられた。表皮細胞の寸ぐ 内側には葉緑体を多く含んだ部位（第 2 図 $\mathrm{A}, \mathrm{ch}$ ），その内 側には細胞壁が肥厚した厚角細胞（第 2 図 $\mathrm{A}, \mathrm{co}$ ），師部と 厚角細胞との間には繊維細胞（第 2 図 A，f）が観察され た. 繊維細胞の内側に師部（第 2 図 A, op）が配列し, 師
部の内側には比較的小さな細胞で分裂活性が高い形成層 （第 2 図 A，c）が存在した。形成層の内側には細胞壁がリ グニン化した多数の道管からなる二次木部（第 2 図 $\mathrm{A}, \mathrm{sx}$ ) の層があった，二次木部の内側は髄となり，髄の二次木部 に近い側には細胞壁がリグニン化中の原生木部 (第 2 図 $\mathrm{A}$, px）があり，その内側に内部師部（第 2 図 A，ip）が点在 していた. 内部師部の内側には皮層に見られたよらな繊維 細胞（第 2 図 A，f）が観察された。髄の柔細胞は比較的大 型の細胞であり，内部にはデンプン粒（第 2 図 A, s）が観
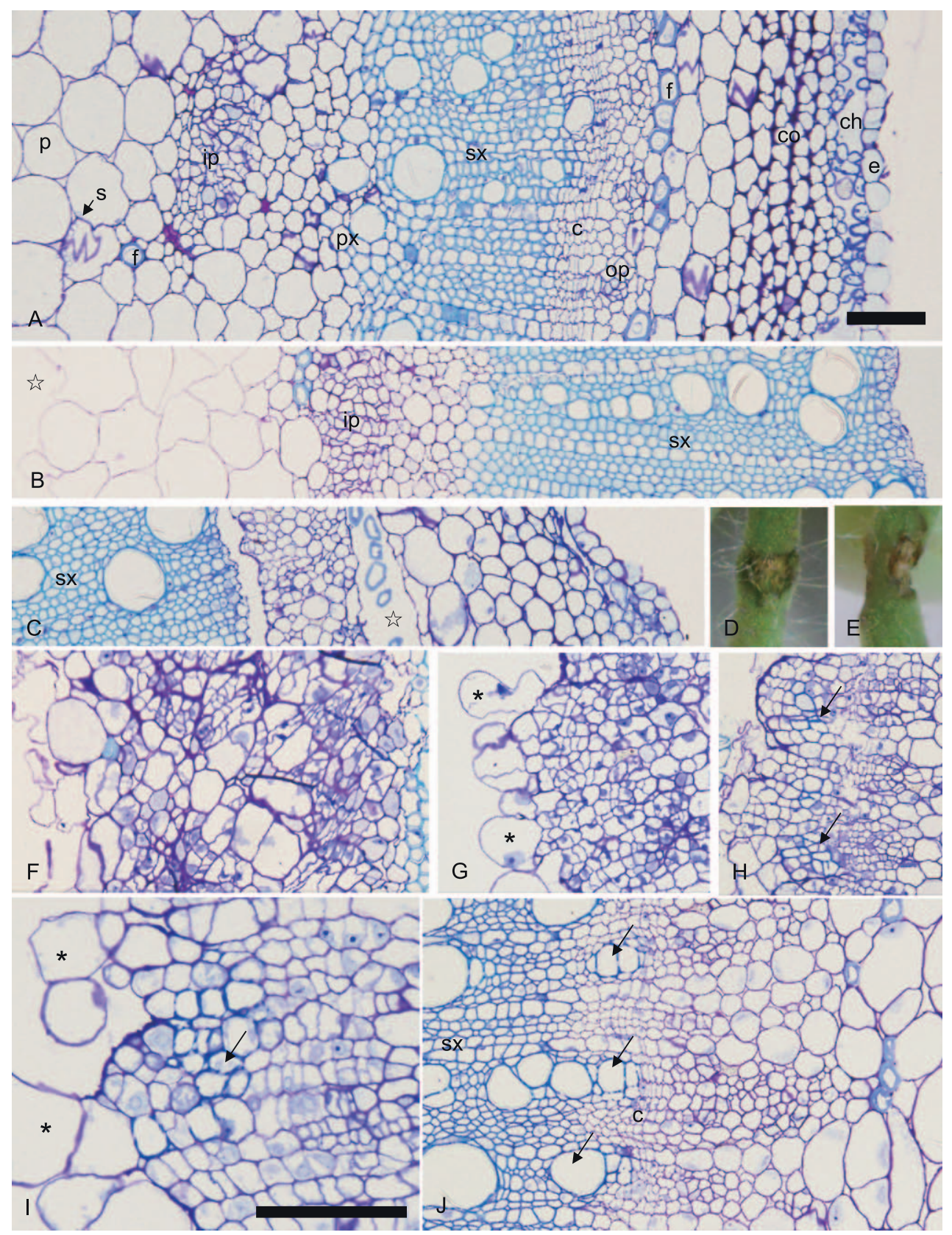

第 2 図 果梗の断面図 $(\mathrm{A} \sim \mathrm{C}, \mathrm{F} \sim \mathrm{J})$

捻枝処理後の果梗 $(\mathrm{D}, \mathrm{E})$, 処理前 $(\mathrm{A})$, 処理 1 日後 $(\mathrm{B} \sim \mathrm{D})$, 処理 3 日後 $(\mathrm{F} \sim \mathrm{J})$, 処理 5 日後 $(\mathrm{E})$

$\mathrm{c}$ : 形成層, co : 厚角細胞, ch : 葉緑体を多く含んだ部位, e : 表皮, f : 繊維細胞, ip : 内部師部, op : 外部師部, p : 䯣, $\mathrm{px}$ : 原生木部, $\mathrm{s}$ : デンプン粒, $\mathrm{sx}$ : 二次木部, * : 肥大した細胞, $\rightarrow$ : 傷道管, 方 : 細胞間隙

スケール : $100 \mu \mathrm{m}(\mathrm{A} \sim \mathrm{C}, \mathrm{F} \sim \mathrm{H}, \mathrm{J})$ ，スケール : $100 \mu \mathrm{m}(\mathrm{I})$ 
察された.

捻枝処理 1 日後には，ペンチで強く挟むことで傷ついた 捻枝部位は乾燥し褐変した（第 2 図 D).内部を顕微鏡で観 察すると二次木部より外側が破壊され消失した部位（第 2 図 B), 二次木部と形成層が乘離した部分（第 2 図 C）が観 察された。 また, 髄の部位, 皮層の繊維細胞周辺なども空 隙が観察された（第 2 図 $\mathrm{B} ， \mathrm{C} ， \succsim$ )。二次木部から剥離し た形成層部位では細胞の配列が乱れ，積み重なったよらな 形成層ではなくなっていた（第 2 図 C).

処理 3 日後, 内部師部周辺は, 新しい細胞壁ができ, 細 胞質の密度が高いメリスティックな細胞となりカルス化し
た（第 2 図 F)。形成層は二次木部から剥離し，形成層部位 で剥離した細胞は水ぶくれ様に肥大していた（第 2 図 $\mathrm{G}$, I，*)。また，剥離した部位の内部では，傷道管 (wound vessels) が形成された（第 2 図 $\mathrm{H}, \mathrm{I} ， \rightarrow$ ）。捻枝処理して剥離した 部位と剥離していない部位の境目あたりの結合部位では, 二次木部の外側に道管が観察でき（第 2 図 $\mathrm{J}, \rightarrow) ，$ 傷道管 と連絡しているものと推測された。 また，その外側には，細 胞が積み重なった形成層の細胞層が観察された（第 2 図 $\mathrm{J}$ ).

処理 5 日後には内部師部周辺がカルス化し増殖した組織 中に，外側で見られたよらな傷道管が形成された（第 3 図 A). 二次木部の外側の，剥離した部位では 3 日後と同じく

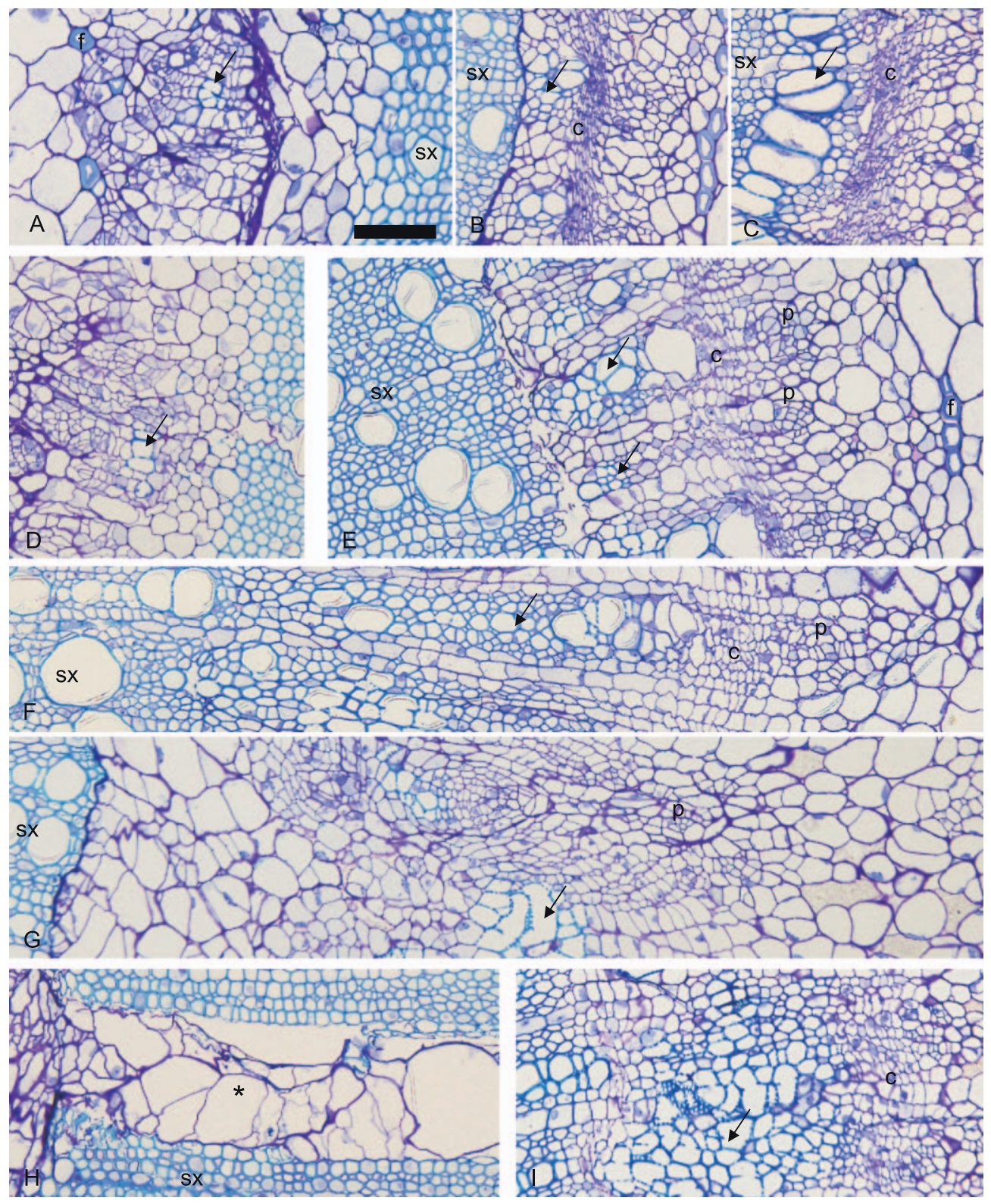

第 3 図 捻枝処理後の果梗断面図 $(\mathrm{A} \sim \mathrm{I})$

処理 5 日後 $(\mathrm{A} \sim \mathrm{C})$, 処理 7 日後 $(\mathrm{D} \sim \mathrm{F})$, 処理 9 日後 $(\mathrm{G} \sim \mathrm{I})$

$\mathrm{c}$ : 形成層, $\mathrm{f}$ : 繊維細胞, $\mathrm{ph}$ : 師部, $\mathrm{sx}$ : 二次木部, * : 肥大した細胞, $\rightarrow$ : 傷道管 スケール : $100 \mu \mathrm{m}(\mathrm{A} \sim \mathrm{I})$ 


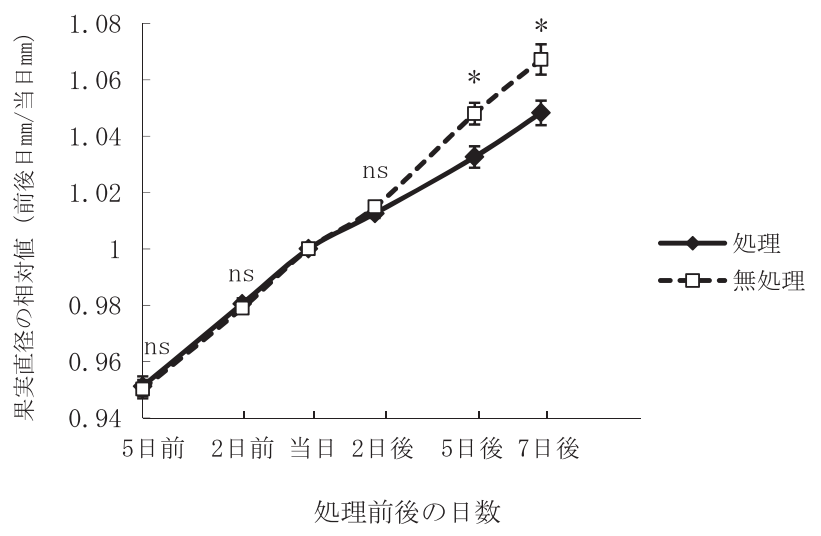

第 4 図 捻枝処理後の果実直径の相対值の変化 *は $\mathrm{t}$ 検定により $5 \%$ 水準で有意差ありを示す

傷道管ができ，その外側には細胞が密に積み重なった形成 層が観察できた（第 3 図 B). 結合部位では元々の二次木部 の外側に比較的大型の道管が観察された（第 3 図 C).

処理 7 日後でも, 内部師部周辺に傷道管が存在した（第 3 図 D, 一). 形成層の外側に細胞が環状に集まった師部組 織の形成が見られた（第 3 図 $\mathrm{E}, \mathrm{p}$ )。ささらに結合部位では 二次木部の外側に細胞が積み重なった木部組織が形成され た（第 3 図 F).

処理 9 日後も, 処理 7 日後同様に, 発達した傷道管が, 剥離した部位の至る所で観察された。 またその周辺には比 較的小さな細胞が積み重なっていた（第 3 図 G, I）。捻枝 処理により二次木部が裂けた部位には肥大した細胞が観察 され，空隙を埋めていた（第 3 図 $\mathrm{H}$ ).

\section{3. 物理的処理が果実肥大に及ぼす影響}

捻枝処理による果実の肥大を明らかにするため，処理当 日の果実の直径を 1 としてその相対值の変化を調查した (第4 図). 処理日まで, 捻枝処理に用いた果実は無処理の 果実と同様に肥大していた. 処理 2 日後, 捻枝処理と無処 理の果実直径の相対值には有意差はなかった. 捻枝 5 日後, 7 日後には捻枝処理したものは, 無処理のものに比べて, 果 実直径の相対值は有意に小さくなった。捻枝処理を行らこ とで果実の肥大率は低下したが，果実肥大そのものが停止 することはなかった.

\section{考察}

山下ら（1994）の報告同様に，果梗への捻枝処理により 裂果の発生は抑制されることが，本試験でも確認できた。

果実発達中の果梗を捻枝処理で物理的に潰した場合, 二 次木部と形成層の間が剥離し，ダメージを受けていた。 こ れは二次木部の道管の細胞壁がリグニン化して強度がある ため比較的硬いのに対し, 形成層より外側の部位の細胞は 比較的柔らかく剥離しやすいためと思われる. 外部からの 観察でも捻枝処理後に果梗は環状に褐色に変色したため, 果梗への捻枝処理は外部師管の連絡を切断したと思われ た.ブドウでは環状はく皮により，師管の連絡を切断する
ことで，着粒安定，着粒肥大促進，成熟促進および着色向 上に効果があることが報告されている（山根ら，2008）。 卜 マト果梗に拈いても, ペンチなどで環状はく皮をすることに より外部師部からの流入を止めることができると思われる.

トマトの果実への水の流入や同化産物の流入に関する報 告は多く, トマト果実への水の流入の主な経路は師管であ ることが推測されている。 これは，果実表面に気孔がなく クチクラ層を通して蒸発するのみであるため, 道管を通る 水の割合が少ないことによる，トマト果実へ流入する師管 液フラックスと道管液フラックスの割合は, 栽培環境, 果 実数などの条件や日々の時間ごとにより変化し，約 60 $85 \%$ が師管により流入していることが示されている (Guichard ら, 2005). Araki ら（2004）は，果梗から果柄へ 水は流入し，果柄へ流入した水の $16 \%$ は果実打よびがくか らの蒸散により消失して, 残りの $86 \%$ が果実肥大に関与す るとし，トマト果実への水の流入は，水ストレス条件下で は道管液フラックスは济とんどなくなり，師管輸送が果実 肥大を維持すると報告している，果実の糖濃度は，師管液 の糖濃度に比例して決定されることも示唆されている （Jan・Kawabata, 2011）。これらの研究は，茥を環状に覆い 熱処理を行うことで生きている師部組織の機能を破壞する ヒートガードリング法を用いて行われている. トマト果柄 へのヒートガードリング処理により，外部師部および内部 師部とも機能が破壊され，道管のみが機能することが示さ れている (Guichardら，2005）。トマト果実への水の流入を 防ぐためには，師管からの水の流入を防ぐ必要があり，環 状はく皮により外部師管の流れを止めることが有効であ る.しかし, トマト果梗では, 髄内部にも内部師部が存在 するため，処理は内部師部まで影響を与えるように処理す る必要があると思われる，本実験での物理的処理で，主に 内部の部位を潰した中心部圧迫処理や，茎に切り込みを入 れ外部師管と道管の半分ほどを切断した切り込久処理で は, 裂果の発生の抑制程度は低く，それは，残った師部お よび道管を通して水が果実へ流入したためと思われた。ぺ ンチにより強く捻枝処理した場合では, 外部師管, 道管, 内部師管にもダメージを与えるため，他の処理よりも裂果 発生が抑制できたと思われた。

二次木部内部の髄の部位に内部師管（internal phloem）が 発達することは古くから報告され（Thompson・Heimsch, 1964）, 内生靯皮部とも呼ばれている（田口，1964）。内部 師部と形成層の外側に位置する外部師部との役割の違いは 不明であり，今後の研究が必要と思われる。

捻枝処理で傷害を受けた果梗では, 細胞の肥大が見られ, その後, カルス化し, 新たな維管束が形成され, 瘉着した. これらの現象は，接ぎ木時での接ぎ木部位で見られる現象 に類似していた，接ぎ木の場合，切断 1 日後，皮層の部位 の細胞の肥大が見られ, その後, カルス化して生長し, 穂 木と台木の隙間を埋め, 4〜 5日後には内部に傷道管 (wound vessels）が現れ，5 日以降にそれらの道管が結合し，新し 
い維管束連絡ができることが報告されている（Jeffree・ Yeoman, 1983). また, 別の報告でも, 接ぎ木接合部には肥 大した細胞（hypertrophic cells）が出現し，カルス化した部 位に新しい形成層が形成され, 接ぎ木 8 日後には新しい道 管と師管が接ぎ木接合部で完全に結合するとされている (Fernandez-Garcia ら，2004）. 切断された維管束では 2, 3 日で傷道管と傷師管（wound-sieve elements）ができ，それ ぞれが連絡してブリッジを形成し，それまでの維管束と再 結合し, その過程に扣いてはいくつかの遺伝子が発現する ことが報告されている（Nishitani ら，2002）。傷害応答時に はジャスモン酸が関与することが示唆されている (Wasternack ら，2006）。 以上のことから，捻枝処理により 傷ついた維管束は, その後, 接ぎ木部位で見られるよらに, カルス化し, 傷道管や傷師管が形成され, 再結合すると思 われた．本実験で処理 3 日後には傷道管が観察でき， 5, 7 日後にはカルス化した内部に新しい維管束の走行が見られ たことから，物理的な破壊処理により，維管束からの水の 流入は一時的に阻害されるが，新しい維管束連絡の形成に より徐々に回復するものと思われた.

以上のことから，果梗を捻枝することで，組織形態的に 維管束が破壊され，果実への水の流れは阻害できることが 確認できた. その後，新たな維管束連絡ができることで, 果実への養分の供給は回復することが示唆された.よって, 山下ら（1994）が提案した捻枝による裂果抑制は効果的で あると考えられた，その際，本研究で示した果梗の内部形 態を考慮し，どの維管束にどれくらいダメージを与えるか 考慮しながら行らことが技術的に重要であると思われる. 現時点では, 裂果の発生程度の予測が困難であり, 捻枝を 定量的に行らことができないため, 果実への養分の供給量 を精密に制御することが困難であるため, 捻枝による裂果 発生抑制技術は，夏〜秋にかけて，裂果の発生が多いと予 想される時期において, 最初の裂果が認められた時に, 商 品果にならないものを軽減する対処方法として使用するこ とが望ましいと思われる。

\section{摘 要}

トマトの裂果発生抑制対策として, 果梗部をペンチで強 く捻枝し，果実への水分流入を阻止する技術がある．物理 的処理が果梗部位の維管束などの組織形態に及ぼす恋化に ついて不明であるため, 処理後の内部構造の変化について 観察した. 捻枝処理 1 日後, 果梗内部では二次木部と形成 層が乘離し，髄の部位，皮層の繊維細胞周辺なども空隙が 観察され，形成層部位は細胞の配列が乱れて扣り，破壊さ れたことが伺えた. 処理 3 日後, 師部周辺では, 新しい細 胞壁が形成され, 細胞質が密となりカルス化した. 形成層 付近の剥離した部位の細胞は肥大していた. カルス化した 内部では, 傷道管が形成された. 処理 5〜9 日後に, カル ス化し増殖した組織中には, 多くの傷道管や, 新たな形成 層，師管が形成され，正常部位と維管束との連絡が観察さ
れた．以上の結果から，果梗を物理的に処理することで維 管束は破壊され，果実への水の流れは一旦阻害されるが, 新たな維管束連絡ができることで，果実への養分の供給は 復活すると思われた。

\section{引用文献}

雨ヶ谷 洋・小沼 寛・中垣至郎. 1984. 近紫外線除去フィ ルムが作物の生育, 害虫の寄生に及ぼす影響（3）トマ トの生育に及ぼす影響. 茨城園試研報. 12: 81-88.

Araki, T., T. Wajima, S. Yoshida and M. Kitano. 2004. Dynamic analysis of growth, water balance and sap fluxes through phloem and xylem in a tomato fruit: short term effect of water stress. Environ. Cont. Biol. 42: 225-240.

Dorais, M., D-A. Demers, A. P. Papadopoulos and W. V. Ieperen. 2004. Greenhouse tomato fruit cuticle cracking. Hort. Rev. 30: 163-184.

Fernandez-Garcia, N., M. Carvajal and E. Olmos. 2004. Graft union formation in tomato plants: peroxidase and catalase involvement. Ann. Bot. 93: 53-60.

Guichard, S., C. Gary, C. Leonardi and N. Bertin. 2005. Analysis of growth and water relations of tomato fruits in relation to air vapor pressure deficit and plant fruit load. J. Plant Growth Regul. 24: 201-213.

Jan, N. E. and S. Kawabata. 2011. Relationship between fruit soluble solid content and the sucrose concentration of the phloem sap at different leaf to fruit ratios in tomato. J. Japan. Soc. Hort. Sci. 80: 314-321.

Jeffree, C. E. and M. M. Yeoman. 1983. Development of intercellular connections between opposing cells in a graft union. New Phytol. 93: 491-509.

Nishitani, C., T. Demura and H. Fukuda. 2002. Analysis of early processes in wound-induced vascular regeneration using TED3 and ZeHB3 as molecular markers. Plant Cell Physiol. 43: 79-90.

野村康弘・鈴木隆志・塩谷哲也. 2006. 遮光資材による夏 秋トマト裂果発生抑制技術. 岐阜中山間農技研報. 5: $11-16$.

鈴木克己・水上宏二 ・土屋 和 - 安場健一郎 - 中野有加 高市益行. 2011. トマト低段密植栽培の二次育苗に扮 ける徒長抑制と果実収量について. 園学研. 10: 183189.

鈴木隆志・野村康弘・嶋津光鑑 - 田中逸夫. 2009. 夏秋卜 マト雨よけ栽培における放射状裂果の発生に及ぼす着 果制限，果房被覆抏よび二酸化炭素施用の影響. 園学 研. 8: 27-33.

鈴木隆志・柳瀬関三. 2005. 夏秋トマト雨よけ栽培におけ る放射状裂果の発生に及ぼす灌水扣よび整枝の影響. 園学研. 4: 75-79.

鈴木隆志・柳瀬関三・塩谷哲也・嶋津光鑑・田中逸夫. 2007. 
夏秋トマト雨よけ栽培に打ける放射状裂果の発生に及 ぼす積算日射量の影響. 園学研. 6: 405-409.

Suzuki, K., K. Yasuba, M. Takaichi, T. Takahashi and T. Hoshi. 2011. Effect of the supplemental lighting on the growth of young plants in second nursery in tomato. Acta Hortic. 907: 269-276.

田口亮平. 1964. 植物生理学大要. 養賢堂. 東京.

高市益行. 2007. 超低コストハウスの開発. 農業機械学会 誌. 69: 4-7.

Thompson, N. P. and C. Heimsch. 1964. Stem anatomy and aspects of development in tomato. Amer. J. Bot. 51: 7-19.

Wada, T., H. Ikeda, K. Matsushita, A. Kambara, H. Hirai and K. Abe. 2006. Effects of Shading in Summer on Yield and Quality of Tomatoes Grown on a Single-truss System. J. Japan. Soc. Hort. Sci. 75: 51-58.
Wasternack, C., I. Stenzel, B. Hause, G. Hause, C. Kutter, H. Maucher, J. Neumerkel, I. Feussner and O. Miersch. 2006. The wound response in tomato-role of jasmonic acid. J. Plant Physiol. 163: 297-306.

渡邊聖文・志和地弘信 - 岩堀修一 ・高橋久光. 2006. 施設 栽培に扣けるトマト果実裂果発生要因の解析. 東京農 業大農学集報. 50: 106-111.

山根崇嘉・浜名洋司・柴山勝利. 2008. ブドウにおける環 状はく皮処理部位のテープによる被覆, 枝齢, 位置お よび師部組織の除去程度がはく皮部のゆ合と果実形質 に及ぼす影響. 園学研. 7: 57-63.

山下文秋・青柳光昭・林 悟朗. 1994. 水耕トマトの低段 密植栽培による周年生産（第 2 報）高温期における裂 果防止対策. 愛知農総試研報. 26: 157-162. 